\title{
IAMJ
}

INTERNATIONAL

AYURVEDIC

MEDICAL JOURNAL

Case Report

ISSN: 2320-5091

Impact Factor: 6.719

\section{AN AYURVEDIC APPROACH IN PSORIASIS - A CASE STUDY}

\author{
$\underline{\text { Anupriya Varma }}^{1}, \underline{\text { Ashish Varma }}^{2}$
}

${ }^{1}$ Consultant, Department of Panchakarma, Janseva Ayurvedic Hospital, Surendra Nagar, Gujarat, India

${ }^{2}$ Assistant professor, Department of Obstetrics and Gynecology, L.G. Hospital, Ahemedabad, Gujarat, India

Corresponding Author: preeva005@gmail.com

https://doi.org/10.46607/iamj1605p5062021

(Published online: September 2021)

Open Access

(C) International Ayurvedic Medical Journal, India 2021

Article Received: 26/08/2021 - Peer Reviewed: 30/08/2021 - Accepted for Publication: 31/08/2021

Check for updates

\section{ABSTRACT}

Background: Psoriasis is a complex, chronic, multifactorial, inflammatory disease that involves hyperproliferation of the keratinocytes in the epidermis, with an increase in the epidermal cell turnover rate. Environmental, genetic, and immunologic factors appear to play a role. The disease most commonly manifests on the skin of the elbows, knees, scalp, and lumbosacral areas, intergluteal clefts, and glans penis. At present, there is no permanent cure other than providing symptomatic relief in modern medical science. Skin disorders respond better to Ayurvedic treatment. Due to psoriasis, the patient also has psychological symptoms like anxiety and depression. In this disease medicine as well as counselling is important in treating it. Case presentation: A 25-years old male, diagnosed with a case of psoriasis, came to our hospital with complaints of itching in the whole body, scaling especially from the scalp, with red patches all over the body for 7 years. He was tired of trying all kinds of medicine and depressed. After a thorough examination, an ayurvedic treatment plan was designed in the form of Panchakarma and oral medicines.

Outcomes: significant improvements were noticed in all symptoms; the duration of treatment was 3 months. And then follow-up was done after every month. PASI score decreased after treatment.

Keywords: Psoriasis, Kustha, Ayurvedic management

\section{INTRODUCTION}

Psoriasis is a common dermatologic disease, affecting up to $1 \%$ of the World's population ${ }^{1}$ both males and females suffering equally ${ }^{[2]}$. The word Psoriasis is derived from the Greek word 'Psora' meaning 'itch' 
and 'sis' meaning 'acting condition'. Psoriasis is a non-infectious, chronic inflammatory disease of the skin, characterized by well-defined erythematous plaques with a silvery-white scale with a predilection for the extensor surface and scalp, and a chronic fluctuating $\operatorname{course}^{[3]}$. In psoriasis, the main abnormality is increased epidermal proliferation due to excessive multiplication of cells in the basal layers. The transit time of keratinocytes is shortened, and epidermal turnover is reduced to 5-6 days from 28-30 days ${ }^{[4]}$. Even though the aetiology is unknown, the factors involved are genetic, biochemical and immunopathological [5]. Precipitating factors like trauma, infections, sunlight, some drugs and emotions may flare up the disease. As there is no available cure for the disease it has remained a great problem for the patients $\left[{ }^{6}\right.$. Patients not only have physical problems but also suffer mental and social distress. Diagnosis of the disease is made mainly based on clinical symptoms that are ${ }^{[7]}$,

- Erythematous sharply defined plaques, covered with silvery-white scales.

- Extensor surfaces primarily involved such as the knees and elbows.

- Koebner's phenomenon is present in the active phase of the disease.

- Wornoff's ring is often present in the healing phase of the disease.

- Auspitz sign and candle grease sign are other classic features of the disease.

The goal of the treatment for the disease is to alleviate symptoms that interfere with the patient's life both physically and socially. In the modern system of medicine coal tar preparations, calcipotriol, retinoid, corticosteroids and ultraviolet radiations are the local measures to manage Psoriasis. The systemic treatment commonly used is photo chemotherapy with PUVA, retinoid, methotrexate and cyclosporine $-\mathrm{A}$ and corticosteroids ${ }^{[8]}$. These medicines usually provide good symptomatic control, but in long term cause several unpleasant side effects. Several types of Psoriasis can be related to certain diseases described in Samhitas. While the description of Kushtha is present since the Vedic period, Kushtha has described in Garuda Purana ${ }^{[9]}$ and almost all Ayurvedic classics after that period i.e. Brihatrayees, Laghutrayi and all texts afterwards. Eka Kushtha is mentioned in all Ayurvedic classics under Kshudra Kushtha and has a predominance of Vata and Kapha dosha ${ }^{[10]}$. The causative factor of Eka Kushtha is the same as Kushtha. Dietary factors such as Viruddha Ahara, excessive consumption of Drava, Snigdha, Guru ahara, Navanna, Vega dharana especially of vomiting are major etiologies. Indulgence in the sinful act and ill Manovritti (negative mentality) are associated mental factors for causing the disease. Acharya Charaka has mentioned the symptoms of Eka Kushtha as Aswedanam, Mahavastu, and Matsyashakalopamam. Acharya Sushruta described its symptoms as Krishna-Aruna Varnata. The etiological factor leads to vitiation of Tridosha especially Vata and Kapha. These Dosha through Tiryakvahini Siras proceed to Bahya Rogamarga i.e. Twacha, Rakta, Mamsa, and Lasika and cause the symptoms of disease. Repeated Samshodhana along with Samshamana is the main line of treatment. Both Antah Parimarjan and Bahiparimarjan therapies have been indicated in Kushtha Roga.

\section{Case Presentation:}

A 25-year-old male patient, diagnosed with psoriasis for 7 years, came to our hospital in Feb- 2021. He had the following chief complaints.

1. Dryness in the whole body

2. Itching with red patches especially in the scalp, elbow, and chest region.

3. Scaling mainly from the scalp region.

\section{History of Present Illness:}

The patient was relatively healthy before 7 years, he noticed itching and red patches which started from the scalp. Gradually itching occurred to the whole body, and patches widened. He took homoeopathy and modern medicine for 7 years but didn't get relief. So, he came to our hospital for further treatment.

Family History: Negative for HTN, DM and any skin diseases.

\section{Clinical Examination:}

CVS: 82/min, RRR, normal S1 S2 sound, no murmur $\mathrm{RS}$ : B/L air entry clear with clear breath sounds 
Mental status: somewhat depressed.

ASSESSMENT: (before treatment Feb-2021)
PASI score: 5.8, Auspitz sign: negative, Candle grease sign: Positive

Table 1: Line of treatment

\begin{tabular}{|c|c|}
\hline Day & Treatment \\
\hline $1^{\text {st }}-5^{\text {th }}$ day & Shodhnarth Snehpan with Panchatikta Ghrita (started from $40 \mathrm{ml}, 15 \mathrm{ml}$ increased every day till $5^{\text {th }}$ day) \\
\hline $6^{\text {th }}$ day & Abhyang with Jatyadi oil, Sarvang Bashpa Svedan with Nimb Patra \\
\hline $7^{\text {th }}$ day & Vaman Karma with Madan phal Churna- 4 gm \\
\hline $8-10^{\text {th }}$ day & Samsarjan Karma \\
\hline $11^{\text {th }}$ to $14^{\text {th }}$ day & Shodhanarth Sneha pan with Pachtikta Ghrita \\
\hline $15^{\text {th }}$ day & Abhyang, Svedan \\
\hline $16^{\text {th }}$ day & Abhyang, Svedan \\
\hline $17^{\text {th }}$ day & Virechana Karma with Dindayal Churna $(5 \mathrm{gm})$ and Erand oil $(50 \mathrm{ml})$ \\
\hline $18^{\text {th }}-20^{\text {th }}$ day & Samsarjan karma \\
\hline $\begin{array}{l}21 \text { st day to } 60^{\text {th }} \\
\text { day }\end{array}$ & $\begin{array}{l}\text { 1. } \quad \text { Sarvang Abhyang with Jatyadi oil } \\
\text { 2. Sarvang Bashpa Svedan with Nimb Patra } \\
\text { 3. Niruh Basti with Pathyadi Kwatha }(320 \mathrm{ml}) \\
\text { 4. } \text { Rakta Mokshan (Sira Vedh) weekly } \\
\text { 5. Nasya karma with Brahmi Ghrita (16-16 drops) } \\
\text { 6. Shamanarth Snehpan }(20 \mathrm{ml} \text { twice a day) } \\
\text { 7. Manjisthadi Kwatha }(40 \mathrm{ml} \text { twice a day) } \\
\text { 8. Kaishor Guggulu }(250 \mathrm{mg}) 3 \text { tabs thrice daily } \\
\text { 9. Gandhak Rasayan }(250 \mathrm{mg}) 2 \text { tabs twice daily } \\
\text { 10. Erand Bhrishta Haritaki }(250 \mathrm{mg}) \text { 5-tab HS } \\
\text { 11. Panchavalkal Kwatha for bath }\end{array}$ \\
\hline
\end{tabular}

Results: The Patient had started improving during treatment and all over recovery was done in 2 months, also new spots which were seen during treatment, were all gone. The patient's PASI score after treatment was 1.4. The candle grease sign was also negative after treatment.

Mode of action of Snehpan in Kushtha: वातोत्तरेषु सर्पिर्वमनं श्लेष्मोत्तरेषु कुषेषु| पित्तोत्तरेषु मोक्षो रक्तस्य विरेचनं चाग्रे॥ (cha.chi. 7)

In the line of treatment of all kinds of Kushtha in Vataj condition, Sarpi is suggested. Here where scaling and dryness are more, Snehpan has a great role in treating disease.

Also, Panchatikta Ghrita is mentioned in Bhaisajya Ratnavali Kushtha Adhikar, it is a widely used medicine for Snehpan for skin diseases. Patola, Guduchi, Nimba etc. which are in Ghrita works on Vata, Kapha and Rakta.
स्नेहस्य पानमिष्टं शुद्धे कोषे प्रवाहिते रक्ते| वायुर्हि शुद्धकोष्ठ कुष्ठिनमबलं विशति शीघ्रम्| (cha.chi.7)

After Shodhana karma, Panchatikta Ghrita was administered as a Shamanarth Snehpan (20 ml twice a day).

Mode of action of Vaman and Virechana:

बहुदोषः संशोध्यः कुष्ठी बहुशोऽनुरक्षता प्राणान् दोषे ह्यतिमात्रह्तते वायुर्हन्यादबलमाशु||| (cha.chi. 7)

Shodhan is highly indicated in patients with skin diseases. Vaman does evacuation of Kapha, and Virechana works on Pitta, so Itching which is mainly due to Kapha decreases. Skin is a sight of Bhrajak pitta, where Virechana works.

Mode of Action of Gandhak Rasayan:

लेलीतक प्रयोगो रसेन जात्याः समाक्षिक: परमः सप्तदशकुष्ठघती माक्षिकधातुश्च मूत्रेण||७०॥ (cha. Chi. 7)

Lelitaka (Sulphur) when administered with the juice of Jati (Amlaki) along with honey is beneficial in 17 
types of Kushtha. Gandhak rasayan Vati is effective in the treatment of Kushtha. Different Bhavana dravyas in Gandhak rasayan act as bactericidal and thus causes blood purification. Bhavana dravyas like Guduchi, Nakesha, Haritaki, Sunthi, has the properties of Katu, Kashaya Rasa and Ushna Virya. Thus, it does Dipana, Pachana, Kledhar and Kaphghna and in this way also acts as Kushtaghna and Kandughna, which helps in curing the disease.

Mode of action of Kaishor Guggulu: In Sharandhar Samhita Madhyama khand-7, the verse "Jayet Sarvani Kushthani"is mentioned about Kaishor Guggulu. The main drug used in Kaishor guggulu is Triphala, which is described in classics in Kushtha Chikitsa.

Mode of action of Manjisthadi Kwatha:

Manjishthadikwath has contents like Manjishtha, Guduchi, Bakuchi, Nimb, Haridra, Patola etc., which not only detoxifies but purifies the blood. Also helps in pacifying Kapha Dosha. Kushtha is a Santarpanottha Vyadhi as per Charak Samhita. Manjishthadikwath also helps to reduce obesity.

\section{Mode of action of Panchtikta Ghrita:}

It is described in Bhaisajya Ratnavali Kushtharogadhikar 114-11, Shaman Sneha pan indications are described in Charak Samhita Sutra sthana.

\section{Mode of action of Raktamokshan:}

Symptoms like Twakvaivarnta, Kandu, Daha will reduce after Siravedha Karma due to Prabhutdosha Nirharan by Siravedha and Raktashudhhi, Sharirlaghvta, Vedana shanti, Twakshotha. According to Acharya Charak and Acharya Sushruta, Shodhan is necessary for dis-ease due to the Bahudosha Avastha. As Kushtha is Tridoshaj Condition, so Siravedha karma (Bloodletting) can be given. Siravedha (bloodletting) procedure is effective to absorb toxic materials so they can be easily evacuated from the body. Besides eliminating Pitta and Kapha Doshas, the main seat of Vata is also purified thereby making Siravedha Karma a truly Tridoshahar procedure. ${ }^{[11]}$

\section{Mode of Action of Nasya Karma:}

In skin diseases, psychological involvement is common. Nothing is better than Nasya where the mind is involved. As "Nasa hi Shiraso Dwaram". Also,
Brahmi has Kushth har qualities mentioned in Bhava Prakash Nighantu- Guduchyadi Varga.

\section{Why Erand Bhrishta Haritaki?}

For patients where bahu dosh involvement is seen, nitya sodhan should be done. Erand Bhrishta haritaki acts as Mridu Virechana and Acts on Pitta dosha. Here it is important to monitor the patient's Bala.

\section{Mode of Action of Niruh Basti:}

As we have seen earlier, when Bahu dosh involvement is seen, Shodhan is essential, Niruh Basti does Mridu Shodhan, and Kushtha is described under indications of Niruh Basti in Charak Samhita Siddhi Sthan.

\section{DISCUSSION}

Causative factors of Kushtha or Psoriasis are faulty diet and lifestyle, which leads to impairment of digestion and aggravation of tridosha. Kapha manifests in the skin and causes the accumulation of toxins. The vitiated three Doshas- Vata, Pitta, Kapha along with impaired Tvak, Rakta, Mamsa and Ambu together constitute seven essential entities that play role in the pathogenesis of this skin disorder. Here scaling was a primary symptom, so vata and Kapha are involved. We go through the exact line of treatment of Kushtha, mainly in skin conditions Katu, Kashay, Tikta aushadhis should be given as shaman. They all do Rakta dhatu Shodhan. The patient was asked to avoid food, which is heavy to digest, sour food, milk, and curd. Where there's chronicity in disease, Shodhan is a must, because due to previous medicines which were taken by the patient, somewhat produces Resistant or Avarana. For removal of that Shodhan is essential. So Niruh Basti, Erand Bhrishta Haritaki was given. Here I must say we should not think of Shodhan as only Panchakarma procedures, but also medicines that do dosha Nirmulan by the nearest route.

\section{CONCLUSION}

Kushtha is described in various classics, and it is considered as Kriccha sadhya Vyadhi. Skin disorders not only affect a patient's social life but also his mental health. So, with treatment, we advised the patient to do meditation. Mainly tikta, katu, Kashay medicines should be given in all skin conditions. 


\section{BEFORE TREATMENT:}

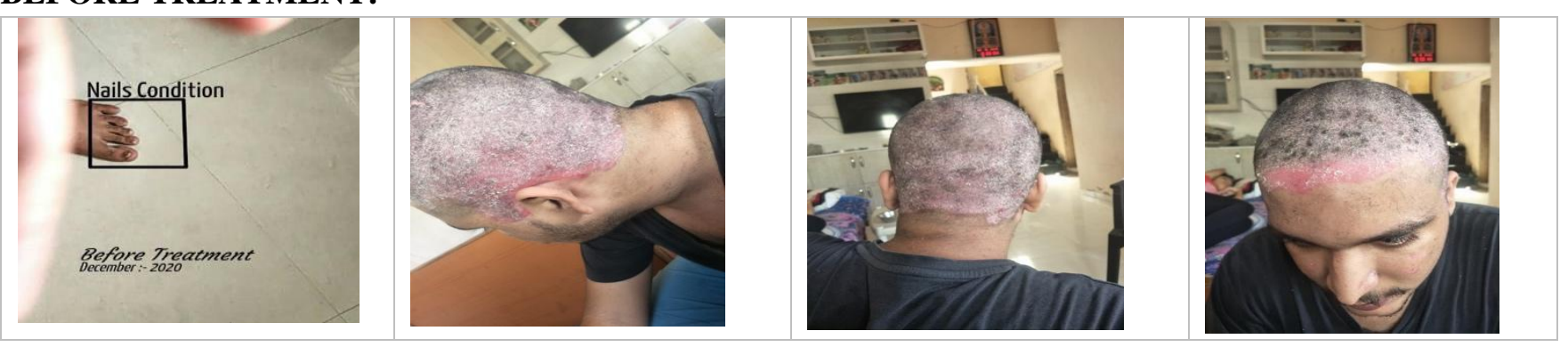

\section{After treatment:}
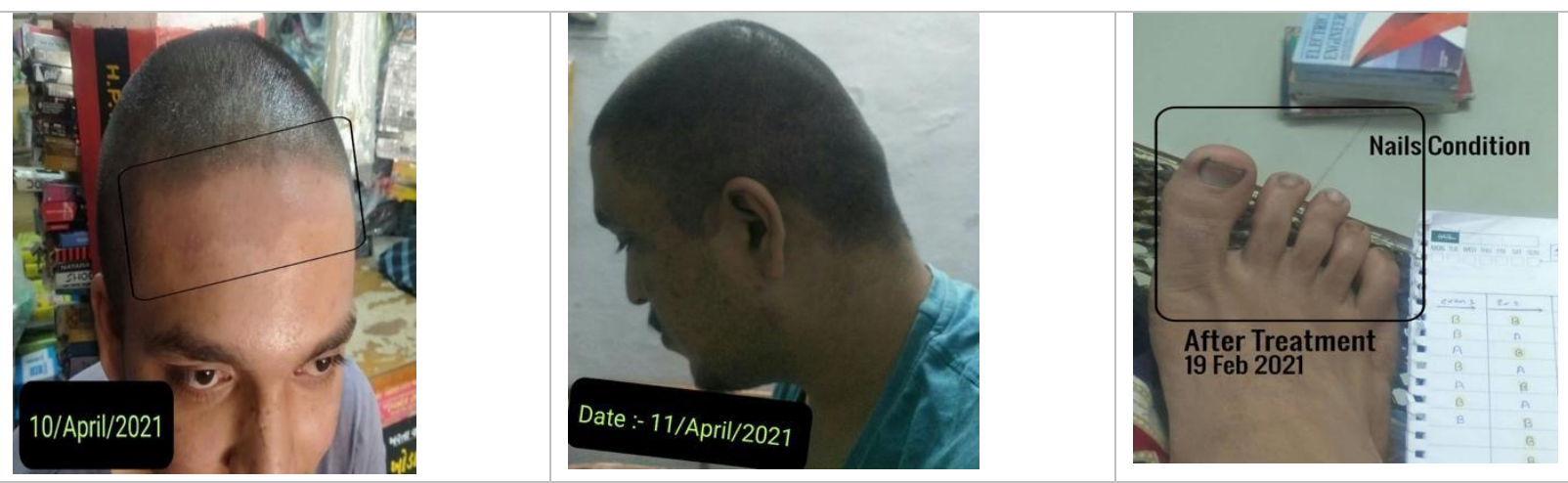

\section{REFERENCES}

1. Fauci, Braunwald, Kasper, Hauser, Longo, Jameson, Loscalzo; Harrison's Principal of Internal Medicine.Vol-1; U.S.A.; 17thedition; McGraw Hill Companies. pg. 315

2. Lee Goldman and Andrew I. Schafer; Goldman's Cecil Medicine. $24^{\text {th }}$ Edition. Elsevier Saunders. Eczemas, photodermatoses, Papulosquamous diseases. pg no. 2517

3. Z. Zaidi and S.W. Lanigan; Dermatology in Clinical Practice, 2010 Springer- Verlag London Limited, Immune system of the skin, pg 185.

4. Davidson's. Principles and practice of medicine.21stedition. Churchill living stone publication, 2010, Chapter- (Diseases of the skin) Pg900.

5. Michael Hertl; Autoimmune diseases of the skin; third edition; Springer Wein New York; pg no. 328-331.

6. Dr Neena Khanna; Illustrated Synopsis of Dermatology and Sexually transmitted diseases; Ed 2005; Peepee publishers and distributors; Pg no.38.

7. DeKorte J, Sprangers MAG, Members FMC et al. Quality of life in patients of Psoriasis: A systemic literature review. J Invest Dermatol Symp Proc 2004; 9:140.

8. Fitzpatrick's. Dermatology in General Medicine; vol-1; seventh edition; Mc Graw hill Companies; Pg 185.
9. Dr Ram Shankar Bhattacharya; Garuda Purana: Maharshi Vedvays; Varanasi; Edition 1964, Chaukhambha Sanskrit Series (Ga. Pu. 1/164/20) Pg no. 38.

10. Pandit Kashinath Pandey and Dr. Gorakhnath Chaturvedi; Charak Samhita, Savimarsha VidyotiniHindi Vyakhya; Varanasi; Ed 2011; Pub-Chaukhamba Sanskrit Sansthana Pg no.253. (Ch. Chi. 7/29-30).

11. Brahma Shankar Shashtri, Laxmipatishashtri, Vidhyotinihinditika, Yogratnakar, Rasayanadhikar, Chaukhambha Publication;2011, Varanasi.

\section{Source of Support: Nil \\ Conflict of Interest: None Declared}

How to cite this URL: Anupriya Varma \& As\&hish Varma: An Ayurvedic Approach In Psoriasis-A Case Study. International Ayurvedic Medical Journal \{online\} 2021 \{cited September 2021\} Available from: http://www.iamj.in/posts/images/upload/3147_3151.pdf 